\title{
TRACE ELEMENTS IN PLASMA AND NUTRITIONAL ASSESSMENT IN PATIENTS WITH COMPENSATED CIRRHOSIS ON A LIVER TRANSPLANT LIST
}

\author{
Thays Santana GUERRA, Nelci Fenalt HOEHR, Ilka de Fátima Santana Ferreira BOIN and \\ Raquel Silveira Bello STUCCHI
}

Received 4/11/2015 Accepted 18/1/2016

\begin{abstract}
Background - In chronic liver disease, trace element levels in plasma are usually low. However, the specific cause and functional implications of this abnormality are yet not well understood. These element levels may decrease as a result of abnormal liver function in patients with cirrhosis and/or malnutrition. Objective - To evaluate the nutritional status and the profile of trace elements in plasma of patients with cirrhosis on a liver transplant list and to correlate them with disease severity. Methods - This cross-sectional study evaluated 31 male patients diagnosed with compensated liver cirrhosis on a waiting list for liver transplant. Nutritional status was objectively evaluated through anthropometry using Mendenhall score and Blackburn classification, subjectively through the Detsky questionnaire and severity of the disease by MELD and CTP score. Trace elements $(\mathrm{Zn}, \mathrm{Se}, \mathrm{Cu}, \mathrm{Ca}, \mathrm{Fe}, \mathrm{Mg}$ and $\mathrm{Mn}$ ) in plasma were analyzed by inductively coupled plasma mass spectrometry (ICP-MS). Statistical analysis was performed using Mann-Whitney test. Results - According to the nutritional assessment $19(61.3 \%)$ were malnourished and $12(38.7 \%)$ were overweight. Regarding disease severity $12(39 \%)$ were classified as Child A, $17(55 \%)$, Child B and $2(6 \%)$ Child C, with $46.9 \%$ of patients with MELD score $>17$. The trace element analysis indicated that $31(100 \%)$ had Mn levels above the reference range, $23(74.2 \%)$ low levels of $\mathrm{Cu}, 29(93.5 \%)$ with deficiency of Se, and $31(100 \%)$ low levels of $\mathrm{Ca}$ and $\mathrm{Mg}$. Disease severity did not show statistical difference between the studied trace elements, in contrast to the nutritional status, in which the malnourished group showed higher levels of $\mathrm{Mn}(P=0.01)$ and $\mathrm{Fe}(P=0.01)$ and low levels of $\mathrm{Zn}(P=0.03)$ when compared to the overweight group. Conclusion - The results showed that the trace elements in plasma are altered in chronic liver disease; without significant correlation to disease severity, but correlated to nutritional status. Malnutrition is present in the patients studied, nonetheless a new scenario with an increase in the prevalence of overweight was verified regardless of the degree of hepatic decompensation.
\end{abstract}

HEADINGS - Nutritional status. Trace elements. Liver cirrhosis. Liver transplantation

\section{INTRODUCTION}

Liver cirrhosis (LC) represents the end stage of many liver diseases ${ }^{(17)}$, being characterized by disorganization of the lobular architecture of the liver, histologically defined by fibrosis and formation of regenerative nodules. The LC is classified according to its morphological characteristics and its clinical manifestations ${ }^{(3)}$.

In $\mathrm{LC}$, one relevant factor is the protein-calorie malnutrition, as patients may experience complications such as ascites, esophageal varices and hepatic encephalopathy ${ }^{(15,27)}$. The prevalence of malnutrition is $65 \%$ to $90 \%$ in cases of advanced liver disease $\mathrm{e}^{(6,24,33)}$.

The malabsorption of nutrients is another important contributor to malnutrition, due to the inability of the body to absorb and use the food ingested ${ }^{(27)}$ as a result of enteropathy, and different degrees of liver failure $^{(22)}$.
Although patients with chronic liver disease usually have low levels of vitamins and trace elements in plasma, the specific cause and functional implications of this abnormality are yet not well clarified ${ }^{(7,33)}$. These elements may present direct liver toxicity or may be reduced as a result of abnormal liver function due to alcoholic cirrhosis and/or malnutrition.

The liver regulates metabolic pathways and the transport of trace elements, and consequently, their bioavailability, tissue distribution and possible toxicity. Trace elements play important roles in various biological processes through activation or inhibition of enzymatic reactions and competition with metalloproteins and other elements for binding sites, affecting the permeability of the cell membrane and other mechanisms $^{(14,20)}$.

Minerals excreted through the biliary system, such as manganese $(\mathrm{Mn})$ and copper $(\mathrm{Cu})$ may be affected by the interruption in the enterohepatic circulation. Magne-

Declared conflict of interest of all authors: none

Disclosure of funding: no funding received

Departamento Gastrocentro - Ambulatório de transplante de fígado. Universidade Estadual de Campinas - UNICAMP, Campinas, SP, Brasil

Correspondence: Thays Santana Guerra. Rua Darcy de Oliveira, 980. Jardim Florence - CEP: 13059-062 - Campinas, SP, Brasil. E-mail: thays_nutri@yahoo.com.br 
sium $(\mathrm{Mg})$, phosphorus $(\mathrm{P})$ and zinc $(\mathrm{Zn})$ levels are depleted in the liver disease patient sowing to malnutrition, malabsorption, alcoholism and the use of diuretics. The bioavailability of the minerals, the tissue distribution and toxicity may be affected by the decrease inproduction of liver carrier protein $s^{(11)}$.

Trace elements such as $\mathrm{Zn}$ and selenium ( $\mathrm{Se}$ ) minimize the harmful effects and progression of several diseases ${ }^{(2)}$. NavarroAlarcón et al. ${ }^{(26)}$ evaluated the serum levels of Se in 50 patients with liver disease ( 38 with hepatitis and 12 with cirrhosis) showing a significant reduction in the concentration of Se in the patients when compared to healthy individuals, especially those with impaired liver function; therefore, individuals with cirrhosis had lower levels than individuals with hepatitis.

The quantification of the essential trace elements such as $\mathrm{Zn}, \mathrm{Se}$, iron $(\mathrm{Fe}), \mathrm{Cu}$, calcium $(\mathrm{Ca}), \mathrm{Mg}$ and $\mathrm{Mn}$, is not a part of the evaluation routine of cirrhotic patients and studies have shown the importance of these elements in liver disease, Thus this work aims to evaluate the nutritional status and profile of trace elements in plasma in patients with liver cirrhosis on a list for transplant and correlate the collected data with disease severity.

\section{METHODS}

\section{Sample}

In this cross-sectional study, biochemical and nutritional assessments were performed in patients attended by the Liver Transplant Outpatient Clinic of the Campinas State University - Unicamp.

The study was conducted after being approved by the Ethics Committee of the Faculty of Medical Sciences of Unicamp (CEP 969/2010) and data collection took place from May 2011 to August 2013. To participate in the study, patients signed an informed consent form (ICF).

The subjects were male patients over 18 years old with a diagnosis of compensated liver cirrhosis, without food restriction or nutritional guidance poly-vitamins usage. Exclusion criteria were: patients with edema of upper (UL) and lower limbs (LL), ascites, in use of diuretics, those who have not agreed to sign the informed consent form, patients who had their biochemical tests canceled due to errors in collection or analysis and those who quit the study. Therefore 31 patients with cirrhosis on a liver transplant list were included.

\section{Data collection and analysis}

After explanation and understanding of the study, the patients signed an informed consent form and then they were interviewed and assessed individually through a specific form. The data recorded were: clinical diagnosis of the patient, the etiology of cirrhosis (alcohol or hepatitis) and classification of disease severity according to the Child-Turcotte-Pugh criteria (CTP) and Model for End Stage Liver Disease Score (MELD), distributing the patients according to MELD score $\leq 17$ and $>17$ for statistical purposes. The anthropometric assessment was done according to weight $(\mathrm{kg})$ and height (m) for body mass index $\left(\mathrm{BMI} \mathrm{kg} / \mathrm{m}^{2}\right)$ calculation, arm circumference ( $\mathrm{AC}$ in $\mathrm{cm}$ ) measured in inelastic anthropometric tape, triceps skinfold thickness (TST in $\mathrm{mm}$ ) measured with Lange ${ }^{\circledR} 2010$ adipometer with scale 0-60 $\mathrm{mm}$, calibrated with a sensitivity of $1 \mathrm{~mm}$ and arm muscle circumference (AMC in $\mathrm{cm}$ ) calculated by AMC formula $\mathrm{AMC}=-(0.0314 \times \mathrm{TST})$.

Anthropometric data AC, TST and AMC collected were evaluated using Mendenhall score and classified according to Blackburn ${ }^{(4)}$ for malnutrition and overweight diagnosis.

The Subjective Global Assessment (SGA) systematized by Detsky et al.$^{(8)}$ was also applied in this period, mainly to assess weight loss, alterations in food intake and reduction of adipose and muscle tissue.

The biochemical evaluation was performed by collecting blood for plasma dosage of trace elements ( $\mathrm{Zn}, \mathrm{Se}, \mathrm{Fe}$, $\mathrm{Cu}, \mathrm{Ca}, \mathrm{Mg}$ and $\mathrm{Mn}$ ) in $\mathrm{BD}$ Vacutainer ${ }^{\circledR}$ Plus tubes (São Paulo, Brazil, 2010) with $4 \mathrm{~mL}$ of heparin. After blood collection, the samples were left to settle for 30 minutes and were then centrifuged for 10 minutes at $2000 \mathrm{rpm}$. After this procedure, $2 \mathrm{~mL}$ of plasma were pipetted into eppendorfs and frozen at $-20^{\circ} \mathrm{C}$.

The samples were homogenized with a vortex (Fisatom, São Paulo, Brazil) for 10 seconds. After stirring, $500 \mu \mathrm{L}$ of each sample were transferred to a graduated plastic Falcon tube of $10 \mathrm{ml}$ and added to $500 \mu \mathrm{L}$ of subdistillednitric acid (Merck, Darmstadt, Germany) in sub-boiling equipment (Destillacid, Eningen, Germany) and $500 \mathrm{uL}$ Hydrogen peroxide $30 \%(\mathrm{w} / \mathrm{v})$ (Merck). The mixture was then stirred with avortex and the bottles were put to settle for one night. Deionized water $(18,2 \mathrm{M} \Omega \mathrm{cm})$ obtained from Millipore MilliQ equipment (Bedford, USA) was added to the settled samples, which were then homogenized with a vortex and centrifuged in a Eppendorfcentrifuge (Hamburg, Germany) for 10 minutes at $20,000 \mathrm{rpm}$ and $25^{\circ} \mathrm{C}$.

The elements $\mathrm{Mg}, \mathrm{Zn}, \mathrm{Fe}, \mathrm{Mn}, \mathrm{Se}$ and $\mathrm{Cu}$ were determined using an inductively coupled plasma mass spectrometer (ICP-MS) (Elan DCR and, PerkinElmer, Norwalk, CT, USA).

The analytical curves were prepared from commercial standards of $1000 \mathrm{mg} / \mathrm{L}$, diluted in nitric acid $1 \%(\mathrm{v} / \mathrm{v})$. Due to the conditions employed in the collision/reaction cellsfor the analysis of analytes, the samples were divided into three groups for determinations of $\mathrm{Mn}, \mathrm{Cu}$ and $\mathrm{Se}$; $\mathrm{Mg}$ and $\mathrm{Zn} ; \mathrm{Fe}$.

Calcium was determined using an inductively coupled plasma optical emission spectrometer (ICP-OES) (iCAP 6300 Duo Series, Thermo Fisher Scientific, UK).

All collected data were collated and included in a database using the System program for Windows (version 9.4. SAS Institute Inc., 2002-2008, Cary, NC, USA).

To describe the sample profile according to the variables studied, frequency tables were made for categorical variables and descriptive statistics for numerical variables.

To study the relationship of trace elements, nutritional profile and nutritional status, disease severity and diagnosis Mann-Whitney test was used. The significance level adopted for this study was $5 \%$. 


\section{RESULTS}

Thirty-one male patients diagnosed with liver cirrhosis were evaluated, with mean age of $53 \pm 8$ years, $11(35.4 \%)$ with liver cirrhosis due to hepatitis C, $11(35.4 \%)$ alcohol and $9(29.2 \%)$ for hepatitis $\mathrm{C}+$ alcohol. Regarding the severity of the disease $12(39 \%)$ were classified as Child A, $17(55 \%)$ Child B and 2 $(6 \%)$ Child $\mathrm{C}$ while $46.9 \%$ of patients had MELD score $>17$ with mean 18.1 \pm 5 . Patient characteristics are shown in Table 1 . Objective nutritional evaluation identified that $61.3 \%$ had malnutrition and 38.7\% overweight; the SGA presented $22(71 \%)$ nourished and $9(29 \%)$ moderately malnourished subjects.

TABLE 1. Patient characteristics

\begin{tabular}{lccc}
\hline Variables & N & $\%$ & Mean \pm SD \\
\hline Age & 31 & - & $53 \pm 8$ \\
Gender M & 31 & 100 & \\
Nutritional assessment & & & \\
$\quad$ Malnourished & 19 & 61.3 & \\
$\quad$ Overweight & 12 & 38.7 & \\
Body mass index $\left(\mathrm{Kg} / \mathrm{m}^{2}\right)$ & 31 & - & $28.2 \pm 4.5$ \\
Arm circumference $(\mathrm{cm})$ & 31 & - & $29.9 \pm 3.5$ \\
Arm muscle circumference $(\mathrm{cm})$ & 31 & - & $25.7 \pm 2.4$ \\
Triceps skinfold thickness $(\mathrm{mm})$ & 31 & - & $13.3 \pm 7.8$ \\
MELD & 31 & - & $18 \pm 5$ \\
$>17$ & & 46.9 & \\
$\quad$ 17 & & 53.1 & \\
Child-Turcotte-Pugh & & & \\
A & 12 & 39 & \\
B & 17 & 55 & \\
C & 2 & 6 & \\
Cirrhosis etiology & & & \\
Alcohol & 11 & 35.4 & \\
Hepatitis C & 11 & 35.4 & \\
Alcohol + Hepatitis C & 9 & 29.2 & \\
\hline
\end{tabular}

Patients with MELD score $\leq 17$ showed lower AMC when compared to patients with MELD scores $>17(P=0.045)$. Nutritional status did not show a statistically significant correlation with disease severity (MELD/CTP). However, malnourished patients had lower weight values, BMI, AC and TST in comparison to the overweight group $(P<0.05)$ (Table 2).
Regarding trace elements in plasma, $31(100 \%)$ patients had Mn levels above the reference values with mean of $3.9 \pm 0.8 \mu \mathrm{g} / \mathrm{L}, 23(74.2 \%)$ low levels of $\mathrm{Cu}$ with a mean of $61.4 \pm 20.9 \mu \mathrm{g} / \mathrm{dL}, 29(93.5 \%)$ Se deficiency with a mean of $64.6 \pm 16.34 \mu \mathrm{g} / \mathrm{L}$ and Fe levels were reduced in $7(22.6 \%)$ patients with a mean of $136 \pm 50 \mathrm{mcg} / \mathrm{dL}$ and $31(100 \%)$ showed low levels of $\mathrm{Ca}$ and $\mathrm{Mg}$ with a mean of $6.4 \pm 1.53 \mathrm{mg} / \mathrm{dL}$ and $0.97 \pm 0.2 \mathrm{mg} / \mathrm{dL}$ respectively. There was no statistical difference between disease severity and the trace elements studied. In relation to nutritional status, there was statistical difference in the malnourished group, which had higher levels of $\mathrm{Mn}$ $(P=0.01)$ and $\mathrm{Fe}(P=0.01)$ and lower levels of $\mathrm{Zn}(P=0.03)$ when compared to the overweight group (Table 2).

\section{DISCUSSION}

Malnutrition is often associated with chronic liver disease, with prevalence of $20 \%$ to $80 \%$ depending on the nutritional assessment method used and the disease severity ${ }^{(5,18,23)}$, and has been correlated to morbidity and mortality associated with liver transplantation ${ }^{(12)}$

Leitão et al. ${ }^{(18)}$ identified about $2 / 3$ of patients with compromised nutritional status in the three stages of the Child classification, therefore unrelated to disease severity. A large multicenter study demonstrated that the prevalence of malnutrition is significantly higher in patients with a more severe hepatic impairment (20\% to $25 \%$ in patients with Child A-B and $>50 \%$ in Child C) ${ }^{(19)}$.

Merli et al. ${ }^{(23)}$ found that $56 \%$ of pre-transplant patients were malnourished and that the presence of malnutrition was not related to the etiology of liver disease. In this study, $61.3 \%$ (19) patients had malnutrition by objective evaluation, as described in Table 1, but there was no correlation to disease severity. The SGA was not able to identify the actual nutritional impairment in the patients with chronic malnutrition, only which alterations in weight or food intake ocurred.

Although malnutrition was often observed in liver cirrhosis patients in the past decade, a new scenario with an increase in the prevalence of overweight obesity has been pointed out. The prevalence of obesity in patients on a transplant list has been greater than $20 \% 0^{(9)}$.

TABLE 2. Levels of trace elements in plasma in malnourished $\mathrm{x}$ overweight patients

\begin{tabular}{|c|c|c|c|c|c|c|c|c|}
\hline & \multicolumn{4}{|c|}{ Malnourished } & \multicolumn{4}{|c|}{ Overweight } \\
\hline Variables & $\mathrm{N}$ & Min & Max & Mean \pm SD & $\mathrm{N}$ & Min & Max & Mean \pm SD \\
\hline $\mathrm{Mn} \mu \mathrm{g} / \mathrm{L}$ & 19 & 2.88 & 4.93 & $4.3 \pm 0.72$ & 12 & 2.3 & 4.9 & $3.4 \pm 0.8^{*}$ \\
\hline $\mathrm{Cu} \mu \mathrm{g} / \mathrm{dL}$ & 19 & 40.3 & 104.7 & $62.7 \pm 23$ & 12 & 40.3 & 97.7 & $59 \pm 18.4$ \\
\hline Se $\mu \mathrm{g} / \mathrm{L}$ & 19 & 46 & 111 & $64.7 \pm 18$ & 12 & 46 & 80 & $65 \pm 14.5$ \\
\hline $\mathrm{Mg} \mathrm{mg/dL}$ & 19 & 0.7 & 1.2 & $1.0 \pm 0.2$ & 12 & 0.5 & 1.2 & $0.9 \pm 0.2$ \\
\hline $\mathrm{Zn} \mu \mathrm{g} / \mathrm{dL}$ & 19 & 72 & 114 & $87 \pm 15$ & 12 & 72 & 130 & $101 \pm 18^{*}$ \\
\hline $\mathrm{Fe} \mu \mathrm{g} / \mathrm{dL}$ & 19 & 70 & 191 & $154 \pm 45$ & 12 & 55 & 191 & $106 \pm 44^{*}$ \\
\hline $\mathrm{Ca} \mathrm{mg/dL}$ & 19 & 4.4 & 8.5 & $6.2 \pm 1.6$ & 12 & 4.4 & 8.6 & $6.8 \pm 1.5$ \\
\hline Weight $(\mathrm{kg})$ & 19 & 57.5 & 88.5 & $77 \pm 8.4$ & 12 & 67 & 126 & $92.5 \pm 16^{*}$ \\
\hline BMI $\left(\mathrm{kg} / \mathrm{m}^{2}\right)$ & 19 & 22.18 & 31.45 & $25.6 \pm 2.1$ & 12 & 24.9 & 39.8 & $32 \pm 4.4 *$ \\
\hline $\mathrm{AC}(\mathrm{cm})$ & 19 & 24 & 32 & $28 \pm 2.3$ & 12 & 28.5 & 38 & $32.7 \pm 3 *$ \\
\hline $\mathrm{TST}(\mathrm{mm})$ & 19 & 5 & 14 & $8 \pm 2.2$ & 12 & 14 & 35 & $21 \pm 6.3^{*}$ \\
\hline
\end{tabular}

$\mathrm{Mn}$ : manganese; Cu: copper; Se: selenium; Mg: magnesium; $\mathrm{Zn}$ : zinc; Fe: iron; Ca: calcium; BMI: body mass index; AC: arm circumference; TST: triceps skinfold thickness. $* P<0.05$. 
Zaydfudim et al. ${ }^{(32)}$ evaluated 154 liver pre-transplant adult patients and observed that $41 \%$ of the patients were overweight, $28 \%$ were obese and concluded that excessive pre-transplant body weight had a negative impact on the rate of improvement of physical quality of life during the first year after transplantation. At three different times of liver transplantation, obesity and very serious overweight were significant predictors of death, and liver transplantation has a higher risk in patients with extreme values of $\mathrm{BMI}^{(16)}$. In this study, we observed that $12(38.7 \%)$ of cirrhotic patients were overweight, thus corroborating with other studies.

Regarding trace elements in plasma, this study observed low levels of $\mathrm{Cu}, \mathrm{Se}, \mathrm{Mg}$ and $\mathrm{Ca}$ and high levels of $\mathrm{Mn}$ in cirrhotic patients.

Abbasi Nazari et al.(1) evaluated $\mathrm{Zn}$ levels in plasma in 50 Iranians with hepatitis $C$ and the mean value was $0.8 \pm 0.2$ $\mathrm{mg} / \mathrm{L}$. They also analyzed cirrhotic and non-cirrhotic patients and found no statistical difference between the two groups in relation to $\mathrm{Zn}$ levels; however, patients with liver disease had lower levels of $\mathrm{Zn}$ when compared to healthy subjects. Although this study did not identify Zn deficiency in the patients, there was a correlation with nutritional status $(P=0.035)$, with lower values in malnourished patients.

Kim et al. ${ }^{(13)}$ evaluated levels of Se by ICP-MS method in 187 Korean patients with liver disease (127 male patients with chronic hepatitis, 30 with LC and 30 with hepatocellular carcinoma-HCC) and compared to 120 healthy individuals. The average of this trace element was $96.4 \pm 51.5 \mu \mathrm{g} / \mathrm{L}$ in patients with hepatitis, $96.4 \pm 32.8 \mu \mathrm{g} / \mathrm{L}$ with $\mathrm{LC}, 67.5 \pm 14.3$ $\mu \mathrm{g} / \mathrm{L}$ with $\mathrm{HCC}$ and $119.4 \pm 28.31 \mu \mathrm{g} / \mathrm{L}$ in healthy men. Se levels were significantly lower in hepatitis and HCC when compared to healthy subjects $(P<0.001)$. In this survey, $93.5 \%$ of the cirrhotic patients had Se deficiency with mean $64.6 \pm 16.3 \mu \mathrm{g} / \mathrm{L}$ through the same analysis method, with no statistical difference between the groups.

Parise et al. ${ }^{(28)}$ studied 31 cirrhotic patients with alcoholic etiology, and 16 had $\mathrm{Mg}$ levels $20 \%$ lower or more, 1 hypocalcemia and $2 \mathrm{Zn}$ low levels. Raj et al. ${ }^{(30)}$ observed that $59.3 \%$ of patients who had undergone liver transplantation showed $\mathrm{Mg}$ deficiency for at least 20 days after surgery. Lopes et al. ${ }^{(21)}$ evaluated 83 patients who underwent liver transplantation and the $\mathrm{Mg}$ level in patients without encephalopathy was $1.6 \pm 0.3 \mathrm{mEq} / \mathrm{L}$. In this study it was observed that $100 \%$ of patients on a liver transplant waiting list had $\mathrm{Mg}$ deficiency with a mean of $0.9 \pm 0.2 \mathrm{mg} / \mathrm{dL}$, which may be associated with alterations in intestinal absorption and/or increased renal excretion.

Nagasue et al. ${ }^{(25)}$ found that $\mathrm{Cu}$ serum level was significantly higher in cirrhotic patients in comparison to normal subjects. Pramoolsinsap et al. ${ }^{(29)}$ demonstrated that $\mathrm{Cu}$ level was high only in patients with hepatocellular carcinoma. Somi et al. ${ }^{(31)}$ studied 60 patients with liver cirrhosis and analyzed the levels of $\mathrm{Zn}, \mathrm{Cu}$ and $\mathrm{Fe}$ by the ICP-MS and the levels of $\mathrm{Zn}$ and $\mathrm{Zn} / \mathrm{Cu}$ decreased with the progression of liver disease; however, $\mathrm{Cu}$ and $\mathrm{Fe}$ serum levels were not statistically different.

In the present study another reality was observe dregarding $\mathrm{Cu}$, as $74.2 \%$ of patients showed low levels of this trace element, with a mean of $61.4 \pm 20.9 \mu \mathrm{g} / \mathrm{dL}$, according to the reference of ICP-MS analysis, differing from the literature. This may be related to the analysis method, since ICP-MS has not been used in most studies with $\mathrm{Cu}$. Iron levels were higher in malnourished patients when compared to overweight patients, with statistical significance of $P=0.01$.

Gonzalez et al. ${ }^{(10)}$ demonstrated the existence of osteopenia in alcoholic people independently of the presence of liver cirrhosis. In this study hypocalcemia was observed in $100 \%$ of the subjects, without correlation between groups. This hypocalcemia can be related to vitamin D deficiency, since the liver is responsible for its absorption.

In conclusion, nutritional status of compensated cirrhotic patients had no association with disease severity (MELD and CTP). However, it was correlated to some trace elements. Although $\mathrm{Cu}, \mathrm{Se}, \mathrm{Mg}$ and $\mathrm{Ca}$ levels were lower in cirrhotic patients, there was also no correlation with disease severity.

\section{Authors' contributions}

Guerra TS: researcher, data collect, search execution, text editing. Hoehr NF: analysis of trace elements. Boin IFSF: guiding research, statistical analysis. Stucchi RSB: joint supervisor. 
Guerra TS, Hoehr NF, Boin IFSF, Stucchi RSB. Oligoelementos plasmáticos e avaliação nutricional em pacientes cirróticos compensados em lista de transplante de fígado. Arq Gastroenterol. 2016,53(2): 84-8.

RESUMO - Contexto - Na doença hepática crônica os níveis plasmáticos de oligoelementos normalmente apresentam-se baixos, mas a causa específica e implicações funcionais desta anormalidade ainda não estão bem esclarecidas. Estes elementos podem estar diminuídos em consequência da função hepática alterada em pacientes com cirrose e/ou desnutrição. Objetivo - Avaliar o estado nutricional e o perfil de oligoelementos plasmáticos dos pacientes com cirrose hepática em lista para transplante e correlacionar com a gravidade da doença. Métodos - Trata-se de um estudo transversal, no qual foram avaliados 31 pacientes do sexo masculino com diagnóstico de cirrose hepática compensada em lista de espera para transplante de fígado. O estado nutricional foi avaliado objetivamente por medidas antropométricas através do escore de Mendenhall e classificado segundo Blackburn, subjetivamente por um questionário sistematizado por Detsky e a gravidade da doença pelo escore MELD e CTP. Os oligoelementos plasmáticos ( $\mathrm{Zn}, \mathrm{Se}, \mathrm{Cu}, \mathrm{Ca}, \mathrm{Fe}, \mathrm{Mg}$ e $\mathrm{Mn}$ ) foram analisados pelo método de espectrometria de massas com fonte de plasma indutivamente acoplado (ICP-MS). Para análise estatística foi utilizado o Teste de Mann-Whitney. Resultados - De acordo com a avaliação nutricional 19 (61,3\%) estavam com desnutrição e $12(38,7 \%)$ com sobrepeso. Em relação à gravidade da doença $12(39 \%)$ foram classificados como Child A, $17(55 \%)$, Child B e $2(6 \%)$ Child C, sendo 46,9\% dos pacientes com o escore MELD >17. Na análise dos oligoelementos $31(100 \%)$ apresentaram níveis de Mn acima dos valores de referência, $23(74,2 \%)$ níveis baixos de $\mathrm{Cu}, 29$ (93,5\%) com deficiência de $\mathrm{Se}$, e 31 (100\%) níveis baixos de Ca e Mg. Em relação à gravidade da doença não houve diferença estatística entre os oligoelementos estudados, já em relação ao estado nutricional o grupo desnutrido apresentou níveis maiores de $\mathrm{Mn}(P=0,01)$ e Fe $(P=0,01)$ e níveis diminuídos de $\mathrm{Zn}(P=0,03)$ quando comparado ao grupo sobrepeso. Conclusão - Os resultados mostraram que os oligoelementos estão alterados na doença hepática crônica, sem associação significativa com a gravidade da doença, mas sim com o estado nutricional. A desnutrição está presente nos pacientes estudados, porém um novo cenário com aumento na prevalência de sobrepeso foi verificado independente do grau de descompensação hepática.

DESCRITORES - Estado nutricional. Oligoelementos. Cirrose hepática. Transplante hepático.

\section{REFERENCES}

1. Abbasinazari M, Behnava B, Panahi Y et al. Plasma Zinc Level in Hepatitis C Patients With or Without Beta Thalassemia Major; Is There Any Difference? Hepat Mon. 2013;13:111-38.

2. Bianchi GP, Marchesini G, Brizi M, et al. Nutritionaleffects of oral zinc supplementation in cirrhosis. Nutr Res. 2000;20:1079-89.

3. Bittencourt PL, Farias AQ, Couto CA. Cirrose hepática. Clínica médica: doenças do aparelho digestivo, nutrição e doenças nutricionais - SP: Manole, 2009 p. 369-83.

4. Blackburn GL, Bistrian BR, Maini BS, Schlamm HT, Smith MF. Nutritional and metabolic assessment of the hospitalized patient. JPEN J Parenter Enteral Nutr. 1977;1:11-22

5. Caregaro L, Alberino F, Amodio P, et al. Malnutrition in alcoholic and virus-related cirrhosis. Am J Clin Nutr. 1996;63:602-9.

6. Carvalho 1, Parise ER. Evaluation of nutritional status of nonhospitalized patients with liver cirrhosis. Arq Gastroenterol. 2006;43:269-74.

7. Cesur S, Cebeci AS, Kavas GO, Yilmaz N, Buyukkagnici DI. Serum copper and zinc concentrations in patients with chronic hepatitis C. J Infect. 2005;51:35-7.

8. Detsky AS, McLaughlin JR, Baker JP, Johnston N, Whittaker S, Mendelson RA, Jeejeebhoy KN. What is subjective global assessment of nutritional status? JPEN J Parenter Enteral Nutr. 1987;11:8-13.

9. Dick AA, Spitzer AL, Seifert CF, et al. Liver transplantation at the extremes of the body mass index. Liver Transpl. 2009;15:968-77.

10. Gonzalez Calvin JL, Garcia Sanches A, Bellot V, Muñoz Torres M, Raysa Alvarez E, Salvatirre Rios D. Mineral metabolism, osteoblastic function and bone mass in chronic alcoholism. Alcohol Alcohol. 1993;28:571-9.

11. Hasse JM, Weseman B, Fuhrman MP, Loeffler M, Francisco Ziller N, Dicceco SR. Nutrition therapy for end stage liver disease: a practical approach. Support Line. 1997; 19:8-15

12. Italian multicentric cooperative project on nutrition in liver cirrhosis. Nutritional status in cirrhosis. J Hepatol. 1994; 21:317-25.

13. Kim IW, Bae SM, Kim YW, Liu HB, Bae SH, Choi JY, Yoon SK, Chaturvedi PK, Battogtokh G, Ahn WS. Serum selenium levels in Korean hepatoma patients. Biol Trace Elem Res. 2012;148:25-31.

14. Kolachi NF, KaziTG, Afridi HI, Kazi NG, Khan S. Investigation of essential trace and toxic elements in biological samples (blood,serum and scalp hair) of liver cirrhotic/cancer female patients before and after mineral supplementation. Clinical Nutrition. 2012;31:967-73.

15. Kondrup J. Nutrition in end stage liver disease. Best practice \& research clinical Gastroenterology. 2006;20:547-60.

16. Lagadinou M, SolomouEE, Velissaris D, Theodorou GL, Karakatza M, Gogos CA. Alterations in T-lymphocyte subpopulations in patients with complicated liver cirrhosis. Diagn Microbiol Infect Dis. 2013;75:348-56.

17. Lefton HB, Rosa A, Cohen M. Diagnosis and Epidemiology of Cirrhosis. Med Clin North Am. 2009;93:787-99.
18. Leitão AVA, Castro CLN, Basile TM, Souza THS, Braulio VB. Avaliação da capacidade física e do estado nutricional emCandidatos ao transplante hepático. Rev Assoc Med Bras. 2003;49:424-8.

19. Leonard J, Heimbach JK, Malinchoc M, Watt K, Charlton M. The impact of obesity on long-term outcomes in liver transplant recipients-results of the NIDDK liver transplant database. Am J Transplant. 2008;8:667-72.

20. Loguercio C, Girolamo V, Federico A, et al. Relationship of blood trace elements to liver damage, Nutritional status, and oxidative stress in chronic nonalcoholic liver disease. Biol Trace Elem Res. 2001;81:245-54.

21. Lopes PJ, Mei MFT, Guardia AC, Stucchi RSB, Udo EY, Warwar MI, Boin IFSF. Correlation Between Serum Magnesium Levels and Hepatic Encephalopathy in Immediate Post Liver Transplantation Period. Transplant Proc. 2013;45:1122-5.

22. Maio R, Dichi JB, Burini RC. Consequências nutricionais das alterações metabólicas dos macronutrientes na doença hepática crônica. Arq Gastroenterol. 2000;37:52-7.

23. Merli M, Giusto M, Giannelli V, Lucidi C, Riggio O. Nutritional Status and Liver Transplantation. J Clin Exp Hepatol. 2011;1:190-8.

24. Merli M, Riggio O, Dally L. Does malnutrition affect survival in cirrhosis? Hepatology. 1996;23:1041-5.

25. Nagasue N, Kolno H, Chang YC, Nakamura T. Iron, copper and zinc levels in serum and cirrhotic liver of patients with and without hepatocellular carcinoma. Oncology. 1989;46:293-6.

26. Navarro-Alarcón M, Serrana HLG, Pérez-Valero V, López-Martínez MC Selenium concentrations in serum of individuals with liver disease (cirrhosis or hepatitis): relationship with some nutritional and biochemical markers. Sci Total Environ. 2002;291:135-41.

27. O'Brien A, Williams R. Nutrition in end-stage liver disease: principle and practice. Gastroenterology. 2008;134:1729-40.

28. Parise ER, Aguiar RC, Carvalho LU, Ivete K. Hypomagnesemia in alcoholic cirrhotics not related to loop diuretic use. Gastroenterol Endosc Dig. 1995;14:54-8.

29. Pramoolsinsap C, Promvanit N, Komindr S, Lerdverasirikul P, Srianujata S Serum trace metals in chronic viral hepatitis and hepatocellular carcinoma in Thailand. J Gastroenterol. 1994;29:610-5.

30. Raj D, Abreo K, Zibari G. Metabolic alkalosis after orthotopic liver transplantation. Am J Transpl. 2003;3:1566-9.

31. Somi MH, Rahimi AO, Moshrefi B, Rezaeifar P, Maghami JG. Nutritional Status and Blood Trace Elements in Cirrhotic Patients. Hepat Mon. 2007:7:27-32.

32. Zaydfudim V, Feurer ID, Moore DE, Wisawatapnimit P, Wright JK, Pinson $\mathrm{CW}$. the negative effect of pretransplant overweight and obesity on the rate of improvement in physical quality of life after liver transplantation. Surgery. 2009; 146:174-80.

33. Zhao VM, Ziegler TR. Nutrition Support in End-Stage Liver Disease. Crit Care Nurs Clin North Am. 2010;22:369-80. 